\title{
宇宙のゆらぎを検出してノーベル物理学賞 Cosmic ripples net physics prize
}

\author{
宇宙論を精密科学へと引き上げるきっかけとなった観測。
}

\author{
Nature Vol.443(489)/5 October 2006
}

Katharine Sanderson and Jenny Hogan
今年のノーベル物理学賞を受賞したの は、実証的な科学ではないとやゆされ ていた宇宙論を、ようやく「自然科学」 へと導いた発見だった。ジョン・マザー とジョージ・スムートが宇宙背景放射 観測衛星 (COBE) を使って行った最も 初期の宇宙の測定は、後に広大な研究 分野を切り開くことになり、世界中の 研究者の関心を引きつけた。

マサチューセッツ工科大学の宇宙論 研究者MaxTegmark は、「かつて宇宙 論は嘲笑の対象だった。現実離れした、 まるで哲学みたいな分野だといってか らかわれたものだ。しかし、今では宇 宙論は精密科学になった」と話す。

COBEの目標は、宇宙の始まりであ るビッグバンから現在までずっと残っ ている熱を測定することだった。この 残光は「宇宙マイク口波背景放射」と よばれ、1940 年代に予測され、1960 年代の測定で確認されていた。

今回のノーベル賞は 2 つの発見に対 して与えられた。まず、マザー率いる チームが行ったマイクロ波背景放射の スペクトル測定が受賞対象となった。 測定の結果、放射は黒体放射のエネル ギー分布をしていることが確かめられ
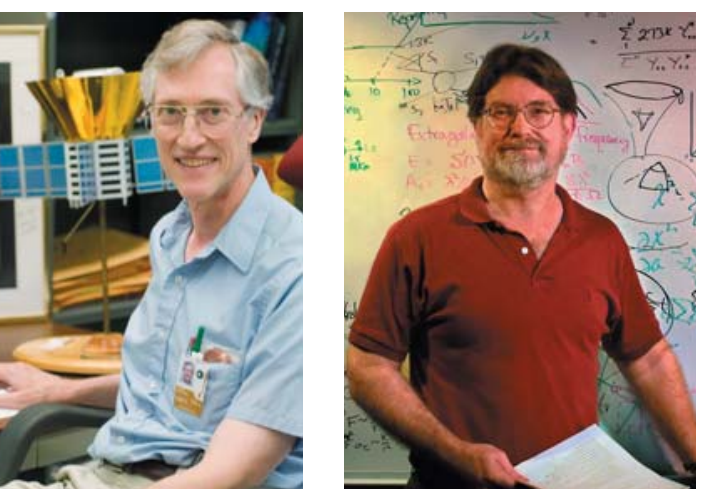

NASA ゴダード宇宙飛行センターのジョン・マザー上 席研究員 (左、60 歳) とカリフォルニア大学バークレー 校 (米) のジョージ・スムート教授 (右、61 歳)。
た。黒体放射とは特定の温度の物体が 出す電磁放射のことで、この場合、現 在よりも数千度高かった時期の宇宙が 出す放射のことをいう。

この測定は、こうした放射の特性か ら宇宙の起源に関する理論を検証でき ることを示した最初のものだった。マ ザーが 1990 年 1 月の会議で成果を披 露すると、参加者らは立ち上がって拍 手を送った。COBEのデー夕を使った 研究を行っていたダラム大学 (英国) の宇宙論研究者 Carlos Frenk は、「こ れまでの私の研究キャリアの中で、ス タンディング・オベーションに立ち会っ たのはこのとき限りだ」と振り返る。

もう一方の受賞者であるスムートは、 マイクロ波背景放射の温度の方向によ るわずかなゆらぎを見つける研究に取 り組んでいた。温度のゆらぎとは、宇 宙の初期構造、つまり、今日の銀河や 星の種を形成した物質の凝集の痕跡を 示すものである。研究者の中には、こ の異方性（方向によって異なること） を検出するにはCOBE の感度では足ら ないと考える者もいたが、スムートは やり遂げた。

1992 年にスムートが温度のゆらぎを 見つけたことを公表すると、世界中の 研究者が拍手喝采した。一連の観測結 果は、ビッグバンが実際に起こったこと を示す、この時点で最も強力な証拠と なった。ケンブリッジ大学の Anthony Lasenby は、「異方性を検出することは、 化石を調べ、その正体を初めて明らかに するような作業だ」と話す。

スムートがこの成果を公表したころ、 Lasenbyもまた、同様の結果を見いだ す寸前だったという。「私たちは、テネ リフェ島（アフリカ北西部カナリア諸 島) での観測に取り組んでいた。温度 ゆらぎの初めての兆候を示しつつあっ たが、もっと時間が必要だった」。

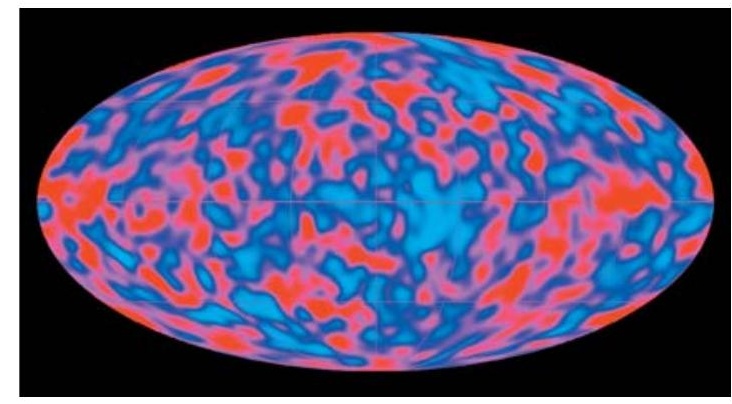

ビッグバンのなごり、宇宙マイクロ波背景放射。

後にCOBE は、「ウィルキンソンマイ クロ波異方性観測衛星」(WMAP)によっ て引き継がれた。WMAP は、COBE 計 画の準備に尽力し、2002 年に亡くなっ た David Wilkinson の名をとって名づ けられた。もし彼が生きていたら、今 回のノーベル賞を共同受賞しただろう という声は多い。詳細に背景放射を調 ベてきた WMAP も、2008 年には欧州 宇宙機関（ESA）の観測衛星「プランク」 によって引き継がれる。

しかし、COBE の観測結果の衝撃に 匹敵するものは今のところない。物理 学者Stephen Hawking は、1992 年 にスムートの観測結果について、「有史 以来最も偉大というわけではないとし ても、今世紀最大の、偉大な発見だ」 と述べて、科学界の興奮を表した。また、 「観測結果を調べることは、神の顔をの ぞき込むようなものだ」というスムー トの発言が論争を招いたこともあった。 「科学に神をもち込むのは、必ずしもよ いことではない」とFrenk は語る。

ケンブリッジ大学の天文学者 George Efstahiou によると、マザーとスムート は不仲となり、異方性の結果の発表方 法についても衝突したという。「しかし、 これで 2 人の名前はノーベル賞の共同受 賞者として永遠に共にあることになる。 おそらく、彼らの不和も解決するのでは ないか」とEfstahiouは話す。 